\title{
Developmental States: Their Historical Absence and their Emergence in Post Conflict Southern Africa
}

\author{
Zibani Maundeni* \\ Department of Political Science, University of Botswana, Botswana
}

\begin{abstract}
Did Southern African states have the developmental focus to make their countries rich? My hypothesis is that a clear focus on making the country rich (with networked infrastructure, effective and functioning technology, functioning health and educational systems, high national income, diversified economy) would dictate that the priorities of the state be ordered in a certain way. My argument is that most Southern African states were historically not properly focused on making their countries rich. My other argument is that most of them are slowly shifting their focus towards making their countries rich.
\end{abstract}

Keywords: Rich country, abundant natural resources, developmental states, Southern Africa states, post colonial states, post cold war.

\section{INTRODUCTION}

This article on developmental states, offers a comparison between Southern African states that went through war such as Angola, Mozambique, Namibia, South Africa and Zimbabwe on the one hand, and states that went through peaceful transformation such as Lesotho, Malawi, Swaziland, Tanzania and Zambia, on the other hand. Emphasis is placed on Angola representing states that went through war, and on Tanzania representing states that went through peaceful transformation. The article argues that states that went through peaceful transformation focused on and pursued continental and rergional liberation, ignoring the need to make their countries rich. It also argues that Southern African states that went through liberation wars, later experienced civil wars that compelled them into high expenditure on security and drafting their best personnel into the war effort, foregoing the goal of making their countries rich. The article ends on a positive note, arguing that, the post conflict era has enabled the Southern African states to shift their focus towards making their countries rich.

The article is divided as follows: section two that follows outlines the developmental state theoretical framework that guides the research. It shows that the concept is most suited to explain the initial absence of, and the current emergence of, states more properly focused on making their countries rich. Richness is here defined in terms of networked infrastructure, possession of effective and functioning technology, existance of functioning health and educational systems, accumulated high national income, a diversified economy. The third section focuses on the history and nationalism of the Southern African states, showing their priorities and structures that worked against making the countries rich.

*Address correspondence to this author at the University of Botswana, Private bag 0022, Gaborone, Botswana; Fax +267 318 5099; Tel +267 3552740; E-mail: Maundeni@mopipi.ub.bw
The last section is on the current state of affairs in Southern Africa, showing that the end of the Cold War and internal conflicts, created more opportunities for a shift in the orientations of the states toward developmental priorities and that the economies are responding in kind.

\section{THEORETICAL FRAMEWORK: FROM WEAK STATES TO DEVELOPMENTAL STATES}

The work that follows uses the concept of 'developmental state' to explain development failure in Southern Africa. First, the concept of the developmental state is parallel to and different from the concept of strong/weak states. The concept of the developmental state is borrowed from Chalmers Johnson [1] who indicates that it is important to consider state priorities in any developmental state research. He starts his definition by categorising the state as either developmental, or regulatory, or pursuing equality, or ideological, or military, or many others. Johnson says these states are explained by their priorities. He defines the developmental state as that which prioritises economic development or pursues developmental nationalism. He says a state attempting to match the economic achievements of Japan must adopt the same priorities as Japan, it must pursue developmental nationalism. It must first of all be a developmental state - and only then a regulatory state, a welfare state, an equality state, or whatever other kind of functional state a society may wish to adopt. Johnson [2] says that for fifty years the Japanese state has given its first priority to economic development. He observes that post war Japan established a developmental state in which there was a clear focus on making the country rich.

Economic nationalism is here differentiated from the simplistic nationalisation of private, especially foreignowned, assets that characterised the politics of the rest of independent Africa in the first twenty years. It refers to a situation in which the state prioritises economic development of the nation over other important considerations such as 
individual wealth and redistribution. In this case, pursuit of ideology is sacrificed for, or follows, economic nationalism. Similarly, the foreign affairs of a state pursuing wealth and economic power is sacrificed for, or subsumed under economic nationalism. Furthermore, a state pursing greatness through wealth and economic power marginalises and suppresses classes calling for redistribution and nationalisation, and sacrifices values of equality and social welfare until later.

In contrast, those using the strong/weak state concept start from Max Weber [3] who argued that states are compulsory associations claiming control over territories and the people within them. They include Skocpol [4], who emphasised that administrative, legal, extractive, and coercive organisations are the core of any state. Thus a state which fails to perform these is a weak state or a failed state. Such states would include Malawi, Tanzania, Zimbabwe and Zambia whose extractive capacity had collapsed in the 1980s and 1990s following the nationalisation of foreign owned businesses and the impositions of strict state control. But it should be noted that while the administrative, legal and extractive capacities of these states collapsed, their coercive capacity (their security systems) remained strong as evidenced by the power of their security forces.

Scholars who use the strong/weak state theory include Migdal [5] who has consistently employed these concepts to explain state failure in Africa, observing that weak states are characterised by the absence of hegemony or the outermost structure that holds society together. His theory is more applicable in situations of nearly collapsed states or contested states such as in Zimbabwe, Democratic Republic of Congo (DRC), Lesotho and Swaziland. But Migdal's [5] theory cannot explain states where hegemony (conceptualised as the outermost structure that holds society together) is clearly present, but where development failure has been extensive and sustained such as Tanzania, Malawi, Zambia, and Madagascar. Vilby [6] shows a typical case of development failure of Tanzania that has enjoyed unity, harmony and orderly transfer of power, and 'yet has seen problems mount up and up'. Many Southern African economies have been equally devastated, either by war or by inappropriate state orientations as shall be shown shortly.

In contrast, the developmental state theory allows us to ask why some countries (even those possessing enormous natural resources, large populations, stable politics and inherited functioning infrastructure) failed to become rich. It allows us to review the focus of the states and their policies, the areas in which resources were channeled into, and the structuring of institutions to pursue state goals.

The developmental state theory allows us to see that even countries with great potential for development (abundant natural resources, large populations and huge landmasses) failed to achieve economic greatness. These include Angola, Tanzania, Zambia and Zimbabwe. Table 1 above shows that, Angola has a land mass of $1,25 \mathrm{mn} \mathrm{km}^{2}$ and 18.5 million inhabitants. It also had functioning infrastructure at independence in 1975. For instance, Mills [7] notes that in Angola: 'Road and rail links had allowed the growth of towns in the interior during the colonial days, opening up the rich agricultural area of the Angolan central plateau'. Angola, possessed huge natural resources such as oil and diamonds, and prices have been good most of the time, including immediately after independence. Mills [7] notes that four of Angola's deepwater areas - Blocks 14, 15, 16 and 17 - are believed by experts to have at least ten billion barrels of oil in recoverable reserves. The mining sector has considerable untapped potential and is projected to show strong growth. Yet independent Angola stagnated economically until recently.

Table $\mathbf{1}$ also shows that Tanzania is among the seven largest states (land mass) in Africa, with a land mass of 0.95 $\mathrm{mn} \mathrm{km}$, including $33,231 \mathrm{~km}^{2}$ of inland water. Tanzania at independence in 1961 had a population of 10 million which had reached 43.7 million people in 2009. It has enjoyed peace since independence (except for a brief war with Uganda). The Policy Forum [8] observes that 'Tanzania is endowed with a number of minerals, including diamonds and gold, and the unique gemstone, Tanzanite'. Duddy [9] adds that Tanzania has islands rich in fisheries that have markets in Europe. Half of Lake Victoria is in Tanzania, providing it with more opportunities for fisheries, tourism and transportation. Tanzania, Zambia and Namibia have huge mineral deposits, including diamonds, gold, uranium, copper and nickel. Yet Tanzanian and Zambian economies stagnated and collapsed until recently.

In contrast, the Democratic Republic of Congo (DRC) was the second largest country in Africa, with a land mass of $2.3 \mathrm{mn} \mathrm{km} \mathrm{km}^{2}$, a population of 66.0 million in 2009 and numerous rich minerals. Kapemba [10] adds that the DRC possesses vast water resources and is extremely rich in mineral resources such as diamonds, coltan, cassiterite, tin, copper, cobalt and gold. Yet the DRC has not been an economic success story. Equally, South Africa has a large land mass $\left(1,221,000 \mathrm{~km}^{2}\right)$ and a large population (50.1 million in 2009) and abundant natural resources. South Africa, Mozambique and Zimbabwe also had well developed infrastructure that could facilitate successful economic development.

Johnson's priority-based developmental state theory point out that economic failure is closely associated with states that marginalised economic development or that did not focus on making their countries rich. Most Southern African states that went through peaceful transition from colonial rule were as economically devastated as those that went through war, as shall be shown below. Herbst and Mills [11] say Angola experienced -1.8 percent GDP average annual real growth rate between 1990 and 2000. Hope and Lekorwe [12] add that Angola had the largest urban poverty (at 67 percent) in Southern Africa in 1996. In 2003, its annual GDP per capita was US\$260 and it was ranked $164^{\text {th }}$ out of 175 countries in the UN's Human Development Index, below countries such as Zambia, Malawi and the DRC. Its urban population's access to safe water was 69 percent, compared to a poor access to sanitation services at 26 percent and access to health care services was not even known.

Similarly, Tanzania, Zambia and Zimbabwe experienced positive development in the early years of independence, but this later declined and stagnated. During the period between the late 1970s and early 1980s (for Tanzania and Zambia) and the 1990s (for Zambia and Zimbabwe) economic performance weakened substantially, leading to an economic crisis. Haule [13] notes that GDP growth in Tanzania declined from an annual average of $5.1 \%$ in the period 1970 - 
Table 1. Comparative Data

\begin{tabular}{|c|c|c|c|c|c|c|c|}
\hline Country & $\begin{array}{l}\text { Population In } \\
\text { Million }\end{array}$ & Area & Life Expectancy & $\begin{array}{c}\text { Population } \\
\text { Growth }\end{array}$ & GDP & $\begin{array}{c}\text { GDP } \\
\text { Growth }\end{array}$ & $\begin{array}{c}\text { GDP } \\
\text { Per capita }\end{array}$ \\
\hline Angola & (2004) $14 \mathrm{~m}$ & $\begin{array}{c}1,246000 \\
\mathrm{~km}^{2}\end{array}$ & 47 & $2.9 \%$ & US $\$ 20.1 b n$ & $11.2 \%$ & $\$ 1303$ \\
\hline Botswana & $1.7 \mathrm{~m}$ & $582000 \mathrm{~km}^{2}$ & 38 & $1.1 \%$ & US $\$ 8.7 \mathrm{bn}$ & $4.6 \%$ & $\$ 5702.14$ \\
\hline DRC & $54.8 \mathrm{~m}$ & $2,345095 \mathrm{~km}^{2}$ & 45 & $2.3 \%$ & US\$6.6bn & $6.3 \%$ & $\$ 111.48$ \\
\hline Lesotho & $1.8 \mathrm{~m}$ & $\begin{array}{c}30355 \\
\mathrm{~km}^{2}\end{array}$ & 37 & $0.9 \%$ & $1.4 \mathrm{bn}$ & $3 \%$ & $\$ 633.18$ \\
\hline Malawi & $11.2 \mathrm{~m}$ & $\begin{array}{c}11848 \\
\mathrm{~km}^{2}\end{array}$ & 38 & $2.1 \%$ & $1.9 \mathrm{bn}$ & $6.7 \%$ & $\$ 152.17$ \\
\hline Mauritius & $1.2 \mathrm{~m}$ & $2040 \mathrm{~km}^{2}$ & 72 & $1 \%$ & $6.1 \mathrm{bn}$ & $4.2 \%$ & 4832.79 \\
\hline Mozambique & $19.1 \mathrm{~m}$ & $\begin{array}{c}799380 \\
\mathrm{~km}^{2}\end{array}$ & 41 & $2 \%$ & US $\$ 5.5 b n$ & & $\$ 320.34$ \\
\hline Namibia & $2 \mathrm{~m}$ & $\begin{array}{c}824116 \\
\mathrm{~km}^{2}\end{array}$ & 40 & $2.2 \%$ & US $\$ 5.5 \mathrm{bn}$ & $4.2 \%$ & $\$ 2233.10$ \\
\hline Swaziland & $1.1 \mathrm{~m}$ & $17364 \mathrm{~km}^{2}$ & 43 & $2 \%$ & US $\$ 2.4 \mathrm{bn}$ & 2.1 & $\$ 2171.71$ \\
\hline South Africa & $46.89 \mathrm{~m}$ & $\begin{array}{c}1,221000 \\
\mathrm{~km}^{2}\end{array}$ & 47 & 0.92 & $\begin{array}{c}\text { US } \$ 211934 \\
\text { Bn }\end{array}$ & $4 \%$ & $\$ 4304.14$ \\
\hline Tanzania & $36.6 \mathrm{~m}$ & $945200 \mathrm{~km}^{2}$ & 43 & $2.2 \%$ & US $\$ 10.9 b n$ & $6.3 \%$ & $\$ 308.09$ \\
\hline Zambia & $10.5 \mathrm{~m}$ & $\begin{array}{c}752612 \\
\mathrm{~km}^{2}\end{array}$ & 36 & $1.8 \%$ & US $\$ 5.4 \mathrm{bn}$ & $4.6 \%$ & $\$ 477.67$ \\
\hline Zimbabwe & $13.2 \mathrm{~m}$ & $390757 \mathrm{~km}^{2}$ & 39 & $1.3 \%$ & US $\$ 4.7 \mathrm{bn}$ & $4.2 \%$ & $\$ 491.12$ \\
\hline
\end{tabular}

Source: Http://www.sadctrade.org/sadcsummarytext

1976 to $1.2 \%$ in the period $1980-1985$. Per capita income growth declined from $2.5 \%$ during $1965-1970$ to $-1.6 \%$ during the 1980-85 periods in Tanzania. The question is whether these states neglected development in pursuance of other important goals?

\section{Developmental Orientation and Developmental Capacity}

There is strong evidence showing that most Southern African states lacked a clearly focused orientation aimed at making their countries rich. To begin with, Angola found itself in a prolonged war situation (1975-2002), compelling the state to develop more orientation towards war and building the capacity of the military (and the security forces in general) and less towards developmental politics. Mills [7] shows that 'Angola's education budget comprised 2.5 per cent of GDP versus defence expenditure of 21.7 per cent in 1999 (The latter was estimated as having increased to around fifty per cent by 2002)' (p128). This means that developmental focus is not always a question of choice, but of circumstances as well.

In addition, the pull-out of superpowers from the Angolan war in the 1990s, compelled the warring factions to focus more on generating internal resources for the war. The pullout was followed by the increase of military spending from
21.5 percent in 1999 to fifty percent in 2002 in Angola. Mills [7] observe that

The conflict in the period 1992-1994 marked a watershed in the history of the Angolan civil war. Stripped of superpower patronage, both sides exploited the country's natural resources to provide the funding they needed for their campaigns, making the accumulation of wealth and the war almost inseparable (p135).

Institutionally, it meant that the Angolan presidency compelled developmental institutions to serve military purposes. This was the situation in Angola, Mozambique, apartheid South Africa and Zimbabwe for many years. These countries developed strong military capabilities, placing the military at the centre of state power and subsuming supposedly developmental institutions such as the central bank and the ministry of development planning, and compelling them to serve military purposes. In military terms, Angola, Mozambique, and Zimbabwe were highly capable and were able to match similarly-structured apartheid regimes that had placed the military at the heart of state power. But in developmental terms, they were very incapable of prioritising and pursuing developmental goals single-mindedly. What this means is that these countries developed superior military 
capabilities and were strong in that regard, but little developmental capabilities and were weak in this regard.

There is a sense in which the Angolan and Mozambican states and liberation armies in Southern Africa could be regarded as predatory during the war period. Typically, the Angolan state extracted natural resources that were used primarily for war purposes which included building a very large army (about 150,000 soldiers as well as possessing sophisticated military equipment), and its involvement in regional wars that had no commercial value to it. According to Kriger [14], Zimbabwe's ZANU, Namibia's SWAPO and Angola's MPLA had similarly built large armies which extracted resources for war from their business communities and their populations (for full titles of political parties and rebel movements, see list of acronyms at the end). Similarly, Maundeni [15] shows that the UNITA and RENAMO rebel movements in Angola and Mozambique built predatory guerrilla armies (of over 90,000 for each). Such large numbers of armed men and women necessarily created a strong military culture at the centre of the state and the opposition, encouraging high military expenditures in an unaccountable and non-transparent manner. These countries got involved in the affairs of neighbouring countries and in regional wars that had no commercial value. In this regard, the liberation and civil wars have produced predatory politics that encouraged high military spending and threatened businesses.

In contrast, Tanzania and Zambia were oriented towards radical pan-African ideologies. This placed them at the centre of regional and continental politics, clouded their developmental vision, alienated their rural populations and alienated nations that possessed international resources that could have been used for development purposes. To begin with, Tordoff [16] quotes President Nyerere of Tanzania observing that "we are not non-aligned on the subject of colonialism and racialism because these are things we have suffered...Tanzania is therefore bitterly opposed to racist minority governments in South Africa and Rhodesia' (p176). Thus, being "bitterly" opposed to racist minority regimes (and not the desire to make Tanzania rich) played a pivotal role in Tanzanian politics. The liberation Committee of the OAU was established in Tanzania, placing the country at the heart of liberation politics and exposing the country to destabilisation associated with it. Azevedo [17] observes that 'FRELIMO was constituted in 1962 in Tanzania with the aim of fighting for Mozambican independence'. Similarly the South African ANC's military wing Umkhonto we Sizwe, as well as ZANU and ZAPU of Zimbabwe, were once based in Zambia.

Tordoff [16] observes that Tanzania and Zambia broke ties with their major donors and investing countries, such as Britain, over its alleged soft approach towards the Rhodesian Declaration of Independence in 1965, and as a way of implementing an OAU decision that called on 'African countries to break ties with Britain if the Rhodesian government had not been defeated by 15 December 1965' (p177). Tordoff [16] also observes that President Nyerere of Tanzania and President Kaunda of Zambia insisted that their countries should not compromise on principles merely for the sake of economic progress ( $\mathrm{p} 178)$. This meant that principles accompanying the politics of being 'bitterly' opposed to racist regimes prevailed over principles of economic development during that era. Thus, both Tanzania and Zambia broke ties with Britain which had, according to Tordoff [16] 'given more economic aid to Tanzania than any other country' (p178). Western companies that remained in these countries were either nationalised or closely monitored and controlled through parastatal-licensing authorities.

In addition, Tanzania and Zambia broke ties with the United States of America over allegations that the CIA planned to assassinate their leaders, particularly Nyerere of Tanzania. Thus, placing Tanzania and Zambia at the heart of regional and continental liberation exposed their presidents to assassination rumours which compelled the states to take decisions that prevented the emergence of a clearly developmental focus. West Germany broke ties with Tanzania over its recognition of East Germany on ideological grounds. Thus, ideological principles took precedence over developmental ones.

Furthermore, Tordoff [16] shows that President Nyerere of Tanzania and President Kaunda of Zambia preferred to concentrate most of their energies on foreign affairs. Tordoff [16] observed about Nyerere that 'The president himself retained no more than nominal responsibility for development planning and delegated his functions to three ministers of state...Though each of the ministers was assigned a distinct sphere of operation, the result was far from satisfactory' (p68). In addition, Nyerere of Tanzania appointed Paul Bomani to be his minister of development planning. Tordoff [16] shows that Mr Bomani was 'something of a political lightweight' [p70], and other ministers easily ignored him. Furthermore, the Tanzanian cabinet hardly focused on strictly developmental matters as its business was not structured. The items that the Tanzanian and Zambian cabinets focused on were dominated by liberation politics in the region and throughout Africa.

In addition, Nyerere of Tanzania was more preoccupied with building a union with Zanzibar which compelled him to build a bloated cabinet, and to arrange state institutions to pursue that goal. According to Tordoff [16]

The main effect of the Union (1964 Union with Zanzibar) on ministerial organisation was to increase the size of the cabinet beyond what would otherwise have been necessary. Of the twenty-three ministers in office on 1 July, 1964 when the Plan became operative, seven (including the First Vice-President, Sheikh Abeid Karume) were Zanzibaris. Discounting the First Vice-President, probably four of these ministers were appointed primarily for political reasons (p68).

In contrast, Maundeni [18] shows that a developmental state such as Botswana would have placed developmental ministries at the heart of state power by making its minister of development to be the first vice president, and therefore preparing him/her to assume the presidency.

Presidents Nyerere of Tanzania, Kaunda of Zambia and Machel of Mozambique, made themselves the ministers of foreign affairs in their respective countries so as to concentrate on the unstable politics of East and Southern Africa. Bana [19] is of the view that Nyerere was so focused on regionalism that he was prepared to delay Tanzanian inde- 
pendence until there was independence in the rest of East Africa. Thus, President Nyerere prioritised the union with Zanzibar, regionalism and African liberation, and delegated development planning to a plurality of three ministers, none of whom had authority over other government ministries. Similarly, the Mozambican, Tanzanian and Zambian states were structured correctly to promote African liberation, and participated actively in the OAU, Frontline States and SADCC. These states were, however, wrongly structured to promote economic development.

In addition, Mozambican, Tanzanian, Zimbabwean and Zambian politics worked against improved developmental state capacity. The forces of Africanisation derailed these states from either developmental focus, or from state structuring towards developmental nationalism. Nyerere faced pressure from the TANU back-bench, TANU members and trade unions. Tordoff [16] notes that 'Faced, however, with a party that was becoming more vociferous in its demands as independence approached, the Prime Minster (Nyerere) was obliged to Africanise senior and middle-grade posts more quickly than he felt was warranted by the small number of Tanganyika graduates and trained personnel then available' (p195). Equal pressure was exerted in Zimbabwe and Zambia from their parties and trade unions. The obvious result was poor developmental state capacity. In Tanzania, Zambia and Zimbabwe, incompetent people were appointed to senior positions of the state. Vilby [6] observes about Tanzania that 'In some places there was some inefficiency since people were appointed to posts that they were not qualified for. Nyerere was well aware of this. This is where we start, he said, and later we'll make up for the things we can't do now. But today we see clearly that quality declined' (p118). So these presidents consciously allowed their states' administrative capacity to be destroyed with the hope of recovering later, without knowing that recovery would be extremely difficult.

What was worse for these countries in terms of developmental state capacity was that Africanisation was defined in racial terms, meaning that only people of African descent (not educated Arabs, Asian and Europeans who were citizens) qualified for senior positions in the public service. These presidents succumbed to Africanisation and became its champion even though it was destroying the administrative capacity of their states. Tordoff [16] writes that 'In February $1961 \mathrm{Mr}$ Nyerere announced that in consultation with the provincial commissioners he had laid plans for more than half of the fifty-eight districts to be in the charge of African officers before the end of the year' (p196). A large number of expatriates left the radically oriented countries which did not have enough trained manpower to replace them. President Masire [20] of Botswana confirmed that a good number of expatriates came to Botswana and South Africa, others went abroad. Bana [19] observes that Lesotho, Swaziland, Tanzania and Zambia had very few post graduates at independence, too few to maintain a competent bureaucracy. Yet Tanzania, Mozambique, Zambia and Zimbabwe expelled expatriates. However, when their economies collapsed, their own educated citizens also left to join the white expatriates in Botswana, Kenya and South Africa.

Developmental states must develop a capacity to mobilise resourcers for development purposes. In this regard, the strength of the state is partly measured in terms of extracting resources. Vilby [6] notes about Tanzania that 'During the socialist period most gold mining died' (p188).The same applied to Zambian copper and Zimbabwean gold. Presidents Nyerere of Tanzania, Mugabe of Zimbabwe and Kaunda of Zambia de-emphasised the role of industries. Nyerere [21] observed that 'We have put too much emphasis on industries... The mistake we are making is to think that development begins with industries. It is a mistake because we do not have the means to establish many modern industries in our country' (pp25-6). Thus, Tanzania, Zambia and Zimbabwe were not aiming to mobilise mining and industries for their development. In addition, Mozambique, Tanzania and Zimbabwe had abolished large scale commercial farming and had replaced it with peasant agriculture. They also prioritised self-reliance and hard work. Their revolutions had also placed emphasis on expanding education for selfreliance. Yet schools in Mozambique, Tanzania, Zambia and Zimbabwe collapsed from lack of funding and poor governance as will be shown shortly.

Another way of extracting resources is to promote a culture of paying for services. Institutions that provide services such as electricity, water and sewerage, must be able to assess all users and encourage (and compel) them to pay for the service. In developmental terms, it is the duty of the central government (particularly the presidency) to assist such service providers to improve their capacity to assess and to enforce payment. The question here is whether Southern African states promoted a culture of paying for services in order to raise revenue for improved capacity for the delivery of better services. The culture of paying for services through local taxation was very weak in these states. Maipose [22] talks of 'the provision of water in Lusaka (Zambia) without installing meters for each household and without disconnecting points. The state had never intended to have each household paying for water'. To promote a paying culture, all these installations would have to be dismantled and reinstituted.

In addition, Mosha [23] notes that land-based sources of revenue were very weak in all these countries. First, valuation rolls were incomplete and out of date. Second, the central governments failed to pay for their many properties in the cities and also failed to pay for the use of the services within the jurisdiction of local authorities (p5). Third, Mosha [23] says many residents, including businesses, NGOs and other institutions also failed to pay rates for their properties. Thus, central governments promoted a culture of nonpayment of rates and for the use of other services. The Zambian Times [24] wrote about 'ongoing accusations in Zambia that the Zambia Telecommunications Corporations (Zamtel) collapsed because the government had not paid up its huge telephone bill. However, the government of Zambia makes a counter claim that Zamtel also owed the government huge sums of money'. This shows that the culture of non-payment for services was widespread in Southern Africa. Vilby [6] quotes a senior citizen in Tanzania confirming that: 'After independence, things happened that people were happy about. Local taxes, that the British had introduced, were abolished. Education and access to the health clinics was free. Everybody should have access and fast so people were happy even though things were very difficult. People didn't understand that taxes helped pay to keep up schools and roads' (p93). This shows that many Southern African states 
prioritised equality and social welfare at the expense of quality services.

Poor government schools (in Mozambique, Tanzania, Zambia and Zimbabwe) made it impossible to have educated and healthy populations that could be mobilised for development purposes. Vilby [6] quotes another Tanzanian citizen to the effect that : 'But already at the end of the 1970s there were huge problems of shortage of funds and materials and, after a time, also shortage of teachers who were badly paid and sometimes weren't paid for several months...In the mid1980s Tanzania's economy was on the brink of a catastrophe. In reality, the country was bankrupt' (p115).

In contrast, Savimbi's UNITA and Dlakama's RENAMO (the opposition movements in Angola and Mozambique) strictly controlled huge populations and denied their government access to them. Maundeni [18] observes that RENAMO controlled $23 \%$ of the counntry and $6 \%$ of the population. These populations were denied access to education and health facilities, therefore not readying them to be mobilised for development purposes later. Those who escaped their control abandoned their villages and went to squat in cities near the capital, the only safe places during the wars.

In Tanzania and Zimbabwe, the states alienated rather than mobolised, many rural dwellers. Under the policy of Ujamaa which was a form of agricultural collectivisation, rural Tanzanians were forcefully relocated and their houses burnt down in the name of development. In this manner, Tanzania failed to mobilise its people for development. A citizen quoted in Vilby [6] observes that:

I lived in a little village and we lived here and there... But suddenly we had to live in a village where the streets were laid out in even lines. We only had to move 600 metres but, all the same, we had to tear our houses down and do it ourselves. Even though I was still almost a child I had my own little hut and I remember when I was forced to pull it down. Everybody had to move. Some people had the roofs of their houses pulled down without getting new ones. There was not much choice. In our village some people kept their fields but they had to go much longer distance to farm them. It became more difficult to guard them from wild animals. There was no planning, and the technology that could have solved some of the problems wasn't there either. People were fed up with everything to do with ujamaa and they were tired of the self help projects that only benefited a few. I think that, even today, this is the reason for the terrible situation in agriculture (pp90-91).

Thus, some Southern African states had capacity to forcefully relocate rural dwellers, but had no capacity to persuade them and to assist them to rebuild their shattered lives. Such politics could not help these countries to become rich.

Mobilising resources for development partly means acquiring access to international resources without incurring huge debt. This implies making the country attractive to foreign international resources. In contrast, Angola, Mozam- bique, Tanzania, Zambia and Zimbabwe did not attract sufficient free financial support from the international community. Instead, they attracted the wrath of the American and South African governments that destabilised them. In developmental state terms, these Southern African states positioned themselves poorly and suffered destabilisation instead of benefiting financially from the international community. According to the United Nations [25], official development assistance to Angola amounted to 2.6 percent and net foreign direct investment was -3.3 percent in 1990, (p205). This clearly shows that these states had failed to position themselves well to benefit from free international support for purposes of achieving socioeconomic development.

In the case of Tanzania, Zambia and Zimbabwe, we have already noted that they alienated the richest countries in the international community, resulting in the countries borrowing heavily from the International Monetary Fund (IMF), the World Bank and the Africa Development Bank, and plunging themselves into unsustainable debt. In addition these states continued to mobilise costly international financial resources. For example, according to the African Development Bank [26], Tanzania borrowed US $\$ 48$ million and secured a grant of only US $\$ 1.32$ million to finance its fifth electricity project aimed at securing, improving and extending sustainable supply to businesses and households in rural towns and suburban areas in Mwanza, Shinyana, Arusha and Dar es Salaam. In developmental state terms, these states mobilised costly rather than free international financial resources and suffered indebtedness.

Developmental politics call for developmentally oriented states that either establish close and mutual relationships with the business community (if they are capitalist societies), or that closely centralise state power around developmentally focussed state institutions. In the first instance, this implies trust and exchange of accurate information between the state and businesses. It also means the state being supportive to business interests and providing the necessary infrastructure to help them make profit which could then be taxed. In contrast, Mozambique, Tanzania, Zambia and Zimbabwe had not been friendly to business. This weakened their states capacity to mobilise private businesses for developmental purposes. In what is representative of several Southern African states, President Nyerere [21] observed that: 'It is our weakness that has led to our being oppressed, exploited and disregarded. Now we want a revolution - a revolution which brings to an end our weakness, so that we are never again exploited, oppressed, or humiliated' (p18). The alleged revolution involved the nationalisation of private business interests and placing them under the ownership of the state.

Evans [27], emphasise on infrastructural power that enables state elites to penetrate, mobilise and persuade the nation to move in a developmental direction. Infrastructural power is about the presence of the state (reaching through bridges, departments, telecommunications, schools, and so on) in all aspects of the nation's life to help make the country rich. In this regard, cities and urban centres are generally regarded as pillars of infrastructure for development. Cities are where major infrastructure is supposedly located, including universities and libraries, telecommunication centres, and markets. However, cities in Southern Africa were primary targets of the war in Angola and Mozambique. Levy [28] 
notes that 'Koito in Angola, besieged for twenty-one months and went through two wars, is regarded as the most destroyed city in Africa, comparable to Sarejevo, with buildings reduced to their skeletons' (p16). Most Southern African cities became extremely impoverished. For instance, Levy [28] says Luanda was characterised by leprous slums, dilapidated buildings that no longer had running water and whose stairs were used as toilets. In addition, Levy [28] notes that 'Huambo City in Angola, was characterised by an abandoned train station with steam-engine trains from the beginning of the century, and no train had entered or left the city in the last twenty years, and whose land transport was completely destroyed and extremely dangerous to use and whose air travel is through Beechcraft planes with decaying cabins, bent doors and broken navigational equipment (p12). Huambo City and Beira in Mozambique had little running water.

Levy [28] observes about Angola that 'Koito's road with Huambo was full of potholes, endless detours through disused fields mined with landmines and thieves who stole from passing vehicles. However, Levy [28] also observes that Cuango, the diamond region of Angola was an exception. 'Here, the MPLA government and UNITA rebels cooperated and spared it the devastation of the war and mined diamonds to finance the war. This region financed the war effort for both sides' ( $\mathrm{p} 135)$. Interestingly, the oil region in Angola was also spared. The offshore and enclave nature of Angolan oil mining placed it out of the reach of the war and enabled government exploitation through partnership with international corporations.

\section{Current State of Affairs in Southern Africa: The Emerging Developmental States}

Most Southern African states (both those that went through war and those that went through peaceful transformation, respectively) have started re-orienting their foreign policies and their general outlook in support of developmental politics. The end of internal wars and the completed political liberation of the whole of Africa have created an environment conducive for the pursuance of developmental goals. Southern African states have learnt to align themselves with rich countries and Chinese presence in the region is a clear demonstration of this. While such an alliance may have strong ideological and historical connections (China supported the liberation wars in the Southern Africa region), it also has an important economic connection.

Madakufamba and Tjonneland [29] note that 'Chinese development finance and investment can be found in nearly all 15 Southern African member countries, but is heavily concentrated in Angola and South Africa'. Sogge [30] adds that 'Chinese trade and investment have radically shifted the pace and direction of Angola's integration. Total trade volume has grown explosively, reaching US\$25.3 billion in 2008, roughly 14 times what it had been in 2000. Angola, is now China's number one trading partner, in sub-Saharan Africa' (p7).

Some of the states have diversified partnerships and positioned themselves strategically with other rich countries. Sogge [30] observes that 'In 2007 the US Assistant Secretary of State for Africa projected Angola as one of the continent's three main hubs alongside Nigeria and South Africa (p8). In addition, Sogge [30] notes that American companies have entered the Angolan economy: 'Chevron alone planned to invest US \$5 billion between 2005 and 2010 (p136). Philip [31] observes that the US secretary of State Hillary Clinton visited Angola in mid-2009. He adds that Angola and the United Kingdom have been strengthening trade relations, with the latter investing in oil and air transport and assisting with demining. Philip also observes that the UK has also been assisting Angola with the electoral process. As a result of partnering with economically successful countries and high oil prices, Angola has achieved one of the fastest growing economies in the world.

Southern African states have stepped up investment in infrastructure to unlock their countries' development potential. Madakufamba and Tjonneland [29] observe that:

China's role in Angola is particularly important where it is also heavily engaged in a number of infrastructure projects (particularly in rail transport) with regional implications...A new oil-backed loan (USD2 billion) with EximBank was secured in 2007 to finance an additional 100 projects. In December 2008 an additional USD 1billion loan from EximBank was secured (p12).

Improving infrastructure (particularly railways, roads and bridges) is enhancing the country's infrastructural capacity, enabling its state to reach all corners of the country to mobilise resources and the population for development.

John [32] notes that Mozambique too has been building infrastructure such as the Zambezi Bridge linking, south and north Mozambique, reconstruction of the Sena railway line linking Beira port to the Moatize coal basin in Tete province, and the permanent dredging of the Beira port which will allow larger ships to call at Beira. President Gubueza [33] of Mozambique reported that the city of Beira in Mozambique is starting to enjoy clean water, better sanitation, better education and health. The Chinese government is also assisting in building hospitals, schools and other infrastructure.

In contrast, investment in infrastructure has been growing slowly in Malawi, Tanzania, Zambia and Zimbabwe. As Vilby [6] noted a few years ago, of Tanzania

The infrastructure is poor, and it is cheaper to transport grain in large quantities by ship from Australia to Tanzania than by truck from inner Tanzania to the coast. The electrical system is poor and demands emergency generators. The qualifications of the labour force are poor, mainly because of the poor educational system (p201).

Thus, poor infrastructure increases the costs of transpotation and hinders internal trade. In the case of Zimbabwe, Bafana [34] reported in July 2009 that the City of Bulawayo was to introduce water rationing, which was last used 25 years ago. Thus, states that are investing little in infrastructure will have to attract more foreign assistance for infrastructure. However, Tanzania has been making some progress in infrastructure development. The African Development Bank [26] noted that Tanzania secured US\$42 million for Zanzibar water and sanitation projects. 
The end of the wars in Angola, Mozambique, Namibia and Zimbabwe provided an opportunity for these states to reorient their focus from war and militant politics, to making their countries rich. The Angolan army has developed some developmental focus by providing surveillance services to oil companies. Sogge [30] observed that 'Since 2004 Chevron has used Israeli-made unmanned aerial vehicles (UAVs) for surveillance of territory, in collaboration with Angola's military' (p11). In developmental state terms, this should be the trend with militaries in the region.

There is evidence that by 2008 , not all Southern African states had completely managed to re-focus to economic nationalism and to sound management of the economy. For instance, some states have been characterised by huge expenditures, most of which are not development related. The Council on Foreign Relations and the Center for Preventive Action [35] report that Angola, 'In 2006 expenditure was budgeted to almost double from its 2005 levels, and the 2007 budget, which was passed by the National Assembly in November, proposed increasing spending by a further 37 percent, mostly to pay for large civil servants' salaries'(p10). The same problem faced Zimbabwe and now South Africa after a series of devastating industrial strikes in the middle of 2009 and beginning of 2010. Thus, spending more on civil servants salaries has either replaced high military expenditure or competes with it, with the potential to derail a reorientation towards developmental goals. In addition, military spending (in Angola, Namibia, Zimbabwe and Mozambique) is still very high to maintain large and sophisticated armies. The Council on Foreign Relations and the Center for Preventative Action [35] reported that:

The Angolan Armed Forces (FAA) has a large, battle-hardened army, jet fighter and helicopter pilot corps, a long-range artillery capacity... Total FAA manpower was approximately 140,000 in 2005 , the army being by far the largest of the services with nearly 130,000 members...In addition, the majority of the military's budget is spent on personnel, including pensions: FAA payroll includes nearly five hundred thousand people. The ongoing need to keep demobilised soldiers employed makes downsizing and streamlining extremely difficult (p27).

Thus, while Angola has not succeeded in scaling down its armed forces and still spends enormous resources on it, Maundeni [15] adds that Mozambique, Namibia and Zimbabwe spend enormous resources on the war veterans and the army as well. Thus, the culture of armed conflicts is still a constrasint on a clear shift to developmental politics. In addition, radical ideologies and the liberation war culture still dominate the politics of states such as Mozambique, Tanzania and Zimbabwe. The threat of the Zimbabwean army to democracy and to the coalition government is legendary. The Daily Nation (Zimbabwe) [38] accused army generals for organising an extremely violent election in 2008 . These generals refused to recognise Morgan Tsvangirai as Prime Minister of Zimbabwe and to salute him until recently. The Daily Nation [38] quotes the Zimbabwean Defence Minister saying that army generals were not obliged to salute Prime Minister Morgan Tsvangirai despite the power sharing agreement with President Robert Mugabe. The minister said there was no legal obligation even though there may be a moral obligation for the generals to salute the prime minister. In contrast, Mmegi [40] quotes former President Masire of Botswana (who was the SADC mediator in Lesotho) accusing the ruling party there, for threatening the stability of the Lesotho nation. In Swaziland it is the King that is accused of threatening reforms in that country.

Angola, DRC and Zimbabwe are still in the process of improving governance in diamond production, to enable it to aid development efforts. The Council on Foreign Relations and the Center for Preventive Action [35] observe that there is a lot of diamond smuggling going on in these countries. In the case of Zimbabwe, the Financial Gazette (Harare) [36] recently reported that the Kimberly Process (KP) investigating team implicated the Zimbabwean army in 'horrific human rights violations' and 'looting of gems at Chiadzwa diamond fields in Manicaland'. The team reportedly called for Zimbabwe to be suspended from the Kimberly Process. This means that some state elites have successfully gained access to diamond proceeds and are diverting these from developmental policies. Diamond proceeds are not yet in the hands of the developmental ministries and departments in the above countries.

Southern African states still need to put more emphasis on human capital. Some states still lack educated and skilled manpower for their socioeconomic activities. For instance, according to the Council on Foreign Relations and the Center for Preventive Action [35], 'Angola began its post-war reconstruction far behind the starting line. In 2005, the Angolan government allocated $\$ 2.5$ billion for public investment, but was capable of spending efficiently only $\$ 1.5$ billion' (p22). Govender and Skagestad [37] observe that the Norwegian Petroleum Directorate undertook a study to assess the skills capacity of the Angolan Ministry of Petroleum and showed that a large number of its employees had little or no education (p17). Vilby [6] noted that the current primary and secondary education systems of these countries are producing illiterate people who cannot be absorbed in the modern economy. Vilby [6] reported that wealthy Tanzanians send their children to primary and secondary schools in Kenya, Uganda and abroad. Wealthy Zimbabweans (including the President and his cabinet ministers) were also doing the same.

In contrast, South African and Chinese mining companies in Tanzania and Zambia have successfully negotiated to import experienced labour, without undergoing a mandatory requirement to train locals for localisation later. However, it must be noted that Angola has been making enormous investment in education. For instance, Philip [31] reported that the City of Huambo recently spent Akz one billion during the first half of 2009 in the construction of 11 schools, school meals, and on other related activities. It also reported that the Huambo province had employed over 1000 new teachers.

In addition, the Council on Foreign Relations and the Center for Corrective Action [35] point out that some of the states have limited capacity to precisely record the monies circulating through their economies. Even extremely resource rich countries such as Angola face this constraint. 'Angola has limited capacity to record precisely the huge 
sums of oil money suddenly pouring into the country, one reason why it remains difficult to obtain accurate government statistics' (p23). The East Africa Business Week [39] adds that Tanzania too lacks the capacity to clearly record the gold proceeds, prompting the World Bank to commit US $\$ 50$ million to help the country to build its monitoring capacity. This is one area that Southern Africa will need to invest in, to boost the capacities of state institutions.

Angola, Tanzania and Zimbabwe are still hostile to private businesses even after abandoning socialist ideologies. The World Bank [41] observes that

Angola is among the most difficult places in the world to do business. More than most countries, Angola strictly regulates business start-up and employment, although there has been some relaxation of employment rules in the past year. Property registration is difficult, and contract enforcement is inefficient. Overall, Angola ranks 156 out of 175 states in the Ease of Doing Business ranking, far behind many of its neighbours in Africa (p10).

Several states grudgingly liberalised their economies through structural adjustment programmes (SAPs) and not out of choice. The World Bank [40] observed that 'of the 326 public enterprises privatised by mid 2003, 122 were sold to Tanzanian citizens (10 of which were sold to employees through the management and employees buy-out scheme), 14 to foreign investors, 190 converted into public ventures'. Policy Forum [8] notes that 'Since, 1998, Tanzania has not only become a player on the world gold market, but also Africa's third largest producer of gold after South Africa and Ghana' (p1). Similarly, copper production improved significantly in Zambia. However, the mining industry is still very small in terms of adding value to GDP in Tanzania. Policy Forum [8] notes that 'Whilst nearly half of Tanzania's exports are now attributed to the mining industry, it only accounts for 3.2 percent of the GDP and 3.6 percent of the Government of Tanzania's total tax revenue' (pp1-2). Policy Forum [8] adds that royalties are ridiculously pegged at 3 percent for gold and 5 percent for diamonds (p6). This is attracting a lot of criticism and drives the anti-privatisation politics.

Policy Forum [8] further observes that an ideological opposition against privatisation is mounting within the ruling parties, among churches, media and civil society in some states, including Malawi, Tanzania, Zambia and Zimbabwe. Critics in Malawi, Tanzania and Zambia speak of the privatisation policy as scandalous. Policy Forum [8], (a Tanzanian association of $50 \mathrm{NGOs}$ aimed at influencing policy processes to enhance poverty reduction, equity and democratisation) believes that privatisation was poorly handled and that corruption was widespread. It charges that profit-making public corporations were sold cheaply to foreigners, and that politicians bought some of the public corporations (including farms that are now poorly run). In Zambia, President Rupiah Banda [42] observed that the anti-privatisation movement is led by the trade unions and people such as the former finance minister, Mr Ng'andu Magande who opposes the privatisation of the Zambia Telecommunications Corporation (ZAMTEL). Critics of the privatisation of ZAMTEL claim that government officials had deliberately made it bankrupt so that it was sold cheaply to their friends. In contrast, President Rupiah Banda [42] observed that 'those who are against the privatisation of ZAMTEL have been in government for a long time, and they did not do anything about it when the company was bleeding to death'.

Policy Forum [8] explains that part of the resistance against privatisation is due to the fact that many governments in the region have little capacity to negotiate with investors for a fair deal. It notes that 'the general set of taxes received by the Government of Tanzania differs from contract to contract, even when it is negotiating with the same company'. It is also clear that the government negotiators were learning as the process went on and this was surely a poor way of handling important negotiations. Critics have compelled governments to mount presidential commissions of inquiry to investigate corruption. Policy Forum [8] reports that in Tanzania, ministers of finance and of energy, and the permanent secretary of the Treasury, were dismissed on charges of corruption. Thus, the politics of Southern Africa is strongly biased towards fighting corruption and little is said about and invested, in boosting the capacity of the government negotiators for a fair deal. Better training and attachment with other successful countries such as Botswana that are well experienced in negotiating mining deals should be promoted.

Some Southern African states have not been able to mobilise their civil societies for developmental purposes. Tanzania is a typical case. The Catholic Information Service Center for Africa [43] observes that in its 2009 budget the Tanzania government proposed to tax religious groups, thus turning them against the government. 'While presenting the 2009/2019 budget in parliament..., Finance and Planning Minister Mustafa Haidi Mkulo said only sacramental and worship materials will be tax exempt'. States in the region will have to learn to deal with the institutions of civil society as partners in development and not just as donor-funded entities to be taxed and oppressed.

\section{CONCLUSION}

This paper has argued that many Southern African states had no developmental focus, pursued state goals that constrained economic development and built state structures that either, prioritised war or foreign policy or radical ideologies, and marginalised development ministries. Economic development requires states to aim to build a rich country. It requires states to place ministries of economic planning at the heart of state power (such as the vice presidency) and to subsume all others to the ideology of economic nationalism. This primarily requires a developmental focused presidency. According to Maundeni [21], a typical example is Botswana where ministers of finance and economic development (Masire, Mmusi and Mogae) were all made vice president, and two of them succeeded to the presidency. Botswana subsumed all other principles under economic nationalism and achieved the goal of making the country rich, attaining the United Nations classification of an upper middle income country. Change of leadership in Southern Africa, the end of the Cold War, IMF and World Bank sponsored privatisation, and the democratisation process, have jointly pushed for political re-orientation towards developmental politics. 
States that carried out localisation in ways that weakened bureaucratic competence, as in Tanzania, destroyed their countries' development potential. A competent and professional bureaucracy (especially in the development ministries) is essential in the pursuit of economic development. Training and experience should precede localisation so that high bureaucratic standards are maintained. In short, regulated localisation that is guided by controlled training of local staff in the best universities around the world is central to maintaining a competent bureaucracy. Localisation for a developmental state should only be done once the locals have received the best training in the same schools that the expatriates attended, have acquired the right experience and are ready to perform the functions attached to the office. More importantly, training priority should be given to developmental ministries. Bureaucratic competence, availability of skilled manpower, and the presence of educationally functioning schools are still the missing ingredients in many states.

Emphasis on infrastructure is central to making a country rich. When Lenin was asked what communism meant, he replied: 'the electrification of Russia'. The emphasis on infrastructure is unmistakable. The establishment of towns and industrial hubs, electricity networks, roads and railway systems, dams, functioning schools and other facilities are crucial for development. Most states in the region have now realised the importance of infrastructure and are putting enormous investment into it. This should be encouraged and supported. Infrastructure makes it possible for the state to mobilise resources and people for development purposes.

Partnering with rich countries is also crucial for development. It is common logic that a state intending to build a rich country associates itself with the rich states. Most states in Southern Africa now associate themselves with rich countries and regions and this is unlocking the region's developmental potential.

\section{ACKNOWLEDGEMENT}

The research for this paper was funded by FOPRISA (Formative Process Research for Integration in Southern Africa) and the Botswana Institute for Development Policy Analysis. I thank the two organisations for their support. I also thank colleagues (Bertha Osei-Hwedie and Mayuyuka Kaunda and the anonymous reviewers for reading and making suggestions that improved this paper.

\section{ACROYNMS}

FOPRISA $=$ Formative Process Research for Integration in Southern Africa

FRELIMO $=$ Frente Libertacao de Mozambique

MPLA $=$ Movement for the Liberation of Angola

OAU = Organisation of African Unity

RENAMO $=$ Mozambique National Resistance Movement

SADCC $=$ Southern Africa Development Coordination Conference

SADC $=$ Southern Africa Development Communnity

SWAPO = South West African Peoples Organisation
TANU $=$ Tanganyika African national Union

UNITA $=$ National Union for the Total Independence of Angola

ZANU $=$ Zimbabwe African National Union

ZAPU $=$ Zimbabwe African Peoples Union

\section{REFERENCES}

[1] Johnson C. MITI and the Japanese miracle: the growth of industrial policy 1925-1975. Sanford, England: Stanford University Press 1982.

[2] Johnson C. The developmental state: odyssey of a concept. In: Woo-Cummings M, Ed. The developmental state in historical perspective. New York, United States of America: Cornell University Press 1999; pp. 32-60.

[3] Weber M. The theory of social and economic organisation, edited with an introduction by Talcott Parsons. New York, United States of America: The Free Press 1964.

[4] Sckocpol T. Bringing the state back in: strategies of analysis in current research. In: Evans PB, Rueshemeyer D, Sckocpol T, Eds. Bring the state back in, Cambridge, New York and Melbourne: Cambridge University Press 1996; pp. 3-43.

[5] Migdal JS. Integration and disintegration: an approach to societyformation. In: L V de Goor LV, Rupesinghe K, Sciarope P, Eds. Between development and destruction: an inquiry into the causes of conflict in post-colonial states. London: Macmillan Press 1996; pp. 91-106.

[6] Vilby K. Independent? Tanzania's challenges since uhuru, Dar es Salaam, Tanzania: E and D Vision 2007.

[7] Mills G. Bigness, development and state dysfunction in Angola. In: Clapham C, Herbst J, Mills G, Eds. Big African States: Angola, Sudan, DRC, Ethiopia, Nigeria and South Africa. Johannesburg: Wits University Press 2006; pp. 123-54.

[8] Policy Forum, The demystification of mining contracts in Tanzania, Dar es Salaam, Tanzania: Policy Forum 2008

[9] Duddy JM. Namibia: diamonds exports drop 30 percent. 2009; AllAfrica.com

[10] Kabemba C. The Democratic Republic of Congo. In: Clapham C, Herbst J, Mills G, Eds. Big African states, Johannesburg 2006; pp. 97-122.

[11] Herbst J, Mills G. Africa's big dysfunctional states: an introductory review. In: Clapham C, Herbst J, Mills G, Eds. Big African states, Johannesburg: Wits University 2006; pp. 1-16.

[12] Hope RH, Lekorwe M. Urbanisation and the environment in Southern Africa: towards a managed framework for the sustainability of cities. J Environ Plan Manag 1999; 42, 6: 837-59.

[13] Haule J. Social and economic impact of privatisation on marketing agency: a case study of Tanzania Handcrafts Marking Corporation (HANDICO). MA[dissertation] Gaborone: University of Botswana 2003.

[14] Kriger N. Guerrilla veterans in post-war Zimbabwe, Cambridge, England: Cambridge University Press 2003.

[15] Maundeni Z. A review of guerrilla veterans in post-war Zimbabwe. Mobilisation 2004; 9, 3: 349-50.

[16] Tordoff W. Government and politics in Tanzania. Nairobi, Kenya Nairobi: Litho ltd 1967.

[17] Azevedo E. The assembly of the Republic of Mozambique, Johannesburg: EISA Working Paper May 2009.

[18] Maundeni Z. State culture and development in Botswana and Zimbabwe. J Mod Afr Stud 2001; 40(1): 105-32.

[19] Bana B. Head of the politics department, University of Dar Es Salaam, Tanzania. Interview with the author, 2009.

[20] Masire QKJ. Former President of Botswana. Gaborone, Botswana. Interviews with the author, 1998.

[21] Nyerere JK. Ujamaa: essays on socialism. Dar es Salaam, Tanzania: Oxford University Press 1968.

[22] Maipose GS. A Zambian professor of Public Administration. Gaborone, Botswana. Interview with the author, 2007.

[23] Mosha AC. Challenges of municipal finance in Africa: Gaborone City, Botswana. Paper presented at the $2^{\text {nd }}$ World Urban Forum Conference on challenges of city financing: Habitat's professionals forum and land urban poverty, organized by the Habitat Professionals Forum and the UN-Habitat 2004. 
[24] The Zambian Times. 2009. Available from: http://www.AllAfrica. com

[25] United Nations. The Human Development Report. New York, United Nations 2002.

[26] The Africa Development Bank. Ghana, Tanzania and AFDB sign US $\$ 153$ Million in loans and grants for energy and poverty reduction 2008. Available from http://www.AllAfrica.com

[27] Evans PB. Predatory, developmental and other apparatuses: a comparative political economy perspective on the third world. Sociol Forum 1989; 4: 561-86.

[28] Levy BH. War, evil and the end of history, London, England: Duckworth 2004.

[29] Madakufamba M, Tjonneland E. A development road show? from Monterrey and Paris to Doha and Accra. Gaborone, Botswana: FOPRISA 2009

[30] Sogge D. Angola: failed yet successful, Pride Working paper 2009.

[31] Philip, D. Angola: UK invests US\$Two Billion in trading[Online]. 2009. Available from http://www.Allafrica.com.

[32] John, T. Mozambique: building more than the Zambezi bridge, 2009. Available from http://www.AllAfrica.com

[33] President Armando Gubueza. Mozambique: investment changing the face of Beira[Online], 2009. Available from: http://www.All Africa.com

[34] Bafana B. Zimbabwe: water rationing looms in Bulawayo, 2009. Available from: http://www.AllAfrica.com
[35] Council on Foreign Relations and the Center for Preventive Action. An independent commission report: towards an Angola strategy: prioritising US-Angola relations. Washington: Council on Foreign Relations 2007.

[36] Financial Gazette (Harare). Zimbabwe: Kimberly process recommends suspension of diamond trade, 2009. Available from: http:// www.AllAfrica.com

[37] Govender S, Skagestad BM. Civil society and oil for development in Angola, Report for IDASA, January 2009.

[38] East African Business Week. Tanzania: country earmarks US\$1.2 billion stimulus package, 2009. Available from: http://www.All Africa.com

[39] The Daily Nation, Zimbabwe: generals not obliged to salute Tsvangirai, 2009. Available from: http://www.AllAfrica.com

[40] Mmegi (Botswana). Lesotho: Masire blames government for unrest, 2009. Available from: http://www.AllAfrica.com

[41] World Bank/International Finance Corporation, Doing Business. Washington, United States of America: World Bank 2007.

[42] President Rupiah Banda, 2009. Available from: http://www.All Africa.com

[43] The Catholic Information Service for Africa (Nairobi). Tanzania: churches lose tax exemption, 2009. Available from: http://www.All Africas.com

(C) Zibani Maundeni; Licensee Bentham Open.

This is an open access article licensed under the terms of the Creative Commons Attribution Non-Commercial License (http://creativecommons.org/licenses/ by-nc/3.0/) which permits unrestricted, non-commercial use, distribution and reproduction in any medium, provided the work is properly cited. 